[Agr. Biol. Chem., Vol. 35, No. 6, p. 813 821, 1971]

\title{
Studies on Urate Oxidase of Candida utılıs
}

\section{Part II. Some Physical and Chemical Properties of the Purified Enzyme}

\author{
By Kimikazu ITAYa, Juichiro Fukumoto \\ and Takehiko YamamoTo \\ Osaka City University, Faculty of Science, Sumiyoshi-ku, Osaka \\ Received October 5, 1970
}

\begin{abstract}
Some physical and chemical properties of urate oxidase (EC 1.7.3.3) isolated from the cells of Candida utilis were investigated. The molecular weight was estimated to be $1.2 \times 10^{5}$ by the equilibrium sedimentation and gel filtration methods. The isoelectric point was determined as 5.4 by the method of density electrofocusing. The enzyme showed a slight absorption at $410 \mathrm{~m} \mu$, and the absorbancy at this wave length was only $3 \%$ of that at $280 \mathrm{~m} \mu$. Contrary to urate oxidase from swine liver, the enzyme from yeast contained a negligible amount of copper, but it contained iron of nearly one atom per mole of the enzyme protein. The yeast urate oxidase was not inactivated by some chelators. However, it was easily inactivated with certain heavy metal ions such as $\mathrm{Hg}^{2+}$, and the inactivated enzyme was reactivated by the addition of thiols, indicating that the enzyme is a sulfhydryl enzyme. The inactivation of the enzyme with urea, on the other hand, was greatly accelerated by the addition of thiols, and some discussion was added to the results obtained.
\end{abstract}

A previous paper ${ }^{11}$ has reported the methods of extraction and purification of urate oxidase (EC 1.7.3.3) from the cells of Candida utilis, a wild yeast, dealing with some properties of the purified enzyme.

Mahler et al. ${ }^{2,31}$ have reported that the urate oxidase isolated from swine liver is a kind of copper enzyme and they have presented a proposed mechanism involving in the enzyme reaction of the metal. On the other hand,
Truscoe et $a l .^{4 \sim 61}$ have recently published several papers covering a wide investigation of the effects of various thiols on urate oxidase of ox-kidney.

The purpose of the present paper is to describe some physical and chemical properties of the purified urate oxidase of Candida utilis, indicating that the enzyme is significantly different from that of animal organs so far reported by several investigators.

\section{MATERIALS AND METHODS}

In this paper, the following abbreviations are used BAL, 2,3-mercapto-1-propanol; PCMB, $p$-chloromercuri benzoate.

1) K. Itaya, T. Yamamoto and J. Fukumoto, $\mathrm{Agr}$. Biol. Chem., 31, 1256 (1967).

2) H. R. Mahler, G. Hübscher and H. Baum, $J$. Biol. Chem., 216, 625 (1955).

3) H. R. Mahler, "The enzyme," Vol. 8, ed. by P. D. Boyer, H. Lardy and K. Myrbäck, Academic Press Inc., New York, N.Y., 1963, p. 285.

\section{Urate oxidase preparation. The urate oxidase of}

4) K. A.C. James, W. P. Tate and R. Truscoe, Enzymol., 37, 131 (1969).

5) R. Truscoe, Biochim. Biophys. Acta, 92, 278 (1964).

6) R. Truscoe, Enzymol., 34, 325 (1968). 
Step

1 Enzyme-induced yeast cells

Soaked in 0.9-satd. NaCl containing

$0.1 \mathrm{M}\left(\mathrm{NH}_{4}\right)_{2} \mathrm{CO}_{3}, 4^{\circ} \mathrm{C}, 24 \mathrm{hr}$.

2 Soaked yeast cells

Suspended in $0.02 \mathrm{M}$ borax, $\mathrm{pH} 9.2$, and dialysed against the same buffer, $4^{\circ} \mathrm{C}, 96 \mathrm{hr}$.

3 Supernatant

Fractionally precipitated between 0.3 and 0.5 satn. of $\left(\mathrm{NH}_{4}\right)_{2} \mathrm{SO}_{4}$.

4 Precipitate

Dialysed against $0.01 \mathrm{M}$ borate buffer, $\mathrm{pH} 8.5$.

Chromatography

by a column of DEAE-cellulose, $0.01 \mathrm{M}$ borate buffer, $\mathrm{pH}$ 8.5. Eluated by a linear gradient of $\left(\mathrm{NH}_{4}\right)_{2} \mathrm{SO}_{4}$, zero to $0.3 \mathrm{M}(0.02 \mathrm{M}$ borate buffer, $\mathrm{pH} 8.5$ ).

6 Eluate

Rechromatography.

7 Eluate

Fractionally precipitated between 0.4 and 0.5 satn. of $\left(\mathrm{NH}_{4}\right)_{2} \mathrm{SO}_{4}$.

Precipitate

Gel filtration by Sephadex G-200, $0.02 \mathrm{M}$ borate buffer, $\mathrm{pH}$ 8.5. Fractionally precipitated between 0.4 and 0.5 satn. of $\left(\mathrm{NH}_{4}\right)_{2} \mathrm{SO}_{4}$.

Precipitate

Desalted by Sephadex G-25.

8 Purified enzyme

DIAgram 1. Purification Procedure of Urate Oxidase of Candida utilis.

Candida utilis was purified according to the method reported previously, ${ }^{11}$ only that the addition of ferric ion to the enzyme for purification by a DEAE-cellulose column chromatography was avoided and the desorbing condition of enzyme from the column was somewhat modified. In Diagram 1 is given the purification procedure of the enzyme. As described later, the purified enzyme sometimes separated into two fractions by gel filtration through a Sephadex G-200 column and thus in the present paper only the enzyme fraction which showed a specific activity of about $10.5 \sim 11.0$ was used. The enzyme of this fraction was ultracentrifugally homogeneous.

2. Activity assay of the enzyme. The enzyme activity assay was carried out by the method described in the previous paper. ${ }^{11}$

3. Specific activity. Specific activity of the enzyme was expressed by the value which was obtained by dividing the enzyme activity per $\mathrm{ml}$ of enzyme solution by the absorbancy at $280 \mathrm{~m} \mu$ per $\mathrm{cm}$ of the solution. The specific activity of the lyophilysed enzyme preparation was obtained in the same way after it had been dissolved in a proper buffer. The solution containing one $\mathrm{mg}$ of the enzyme preparation per $\mathrm{ml}$ gave the absorption value of 1.17 at $280 \mathrm{~m} \mu \mathrm{cm}^{-1}$.

4. Measurement of molecular weight. Measurement of molecular weight was conducted by the methods of equilibrium sedimentation according to Archibald? and gel filtration by a column of Sephadex G-200.

5. Analyses of metals. Analysis of iron in the enzyme preparation was carried out by the chelate titration method using o-nitrosoresorsinol monomethyl ether. Iron was also checked by the electron spin resonance method. Analysis of copper was done by the atomic absorption spctrophotometric method using Nippon Jarrel-ASH, Model AA-1E. Copper was also analysed by the radioactivation method.

\section{EXPERIMENTAL RESULTS}

\section{Molecular weight of the enzyme}

Measurement of molecular weight of the urate oxidase by the Archibald method was kindly conducted at the Institute for Protein Research, Osaka University. In Fig. 1 is shown the sedimentation pattern. From Fig. 1, the sedimentation constant was estimated to be 7.0 at $24.8^{\circ} \mathrm{C}$ and at 0.1 of ionic strength and the molecular weight was calculated to be $1.2 \times 10^{5}$ from the Archibald run shown in Fig. 2.

For measurement of the molecular weight by the gel filtration method was used a column of Sephadex G-200. Several enzymes of known molecular weights were used as references. As can be seen from Fig. 3 the molecular weight of urate oxidase determined by the gel filtration method was almost the same to that obtained by the equilibrium sedimentation method.

7) W.J. Archibald, J. Phys. Chem., 51, 1204 (1947). 

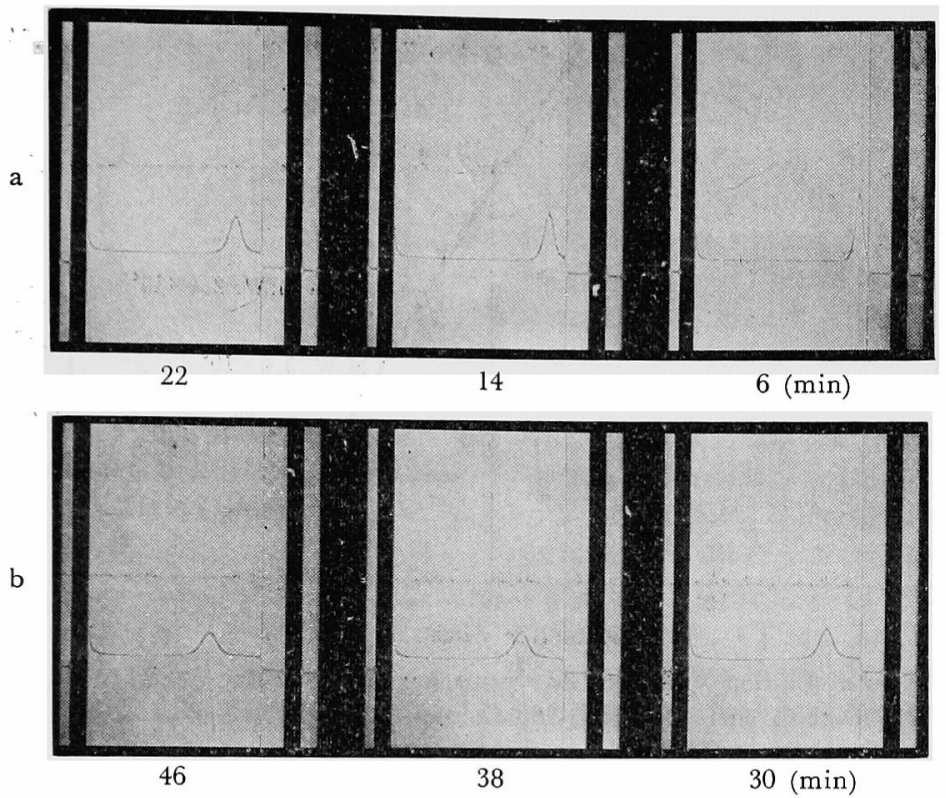

FIG. 1. Ultracentrifugal Pattern of Urate Oxidase of Candida utilis. (Enzyme, $0.96 \%$ in $0.033 \mathrm{M} \mathrm{Na}_{2} \mathrm{HPO}_{4} ; 24.8^{\circ} \mathrm{C}, 50,000 \mathrm{rpm}$ ).

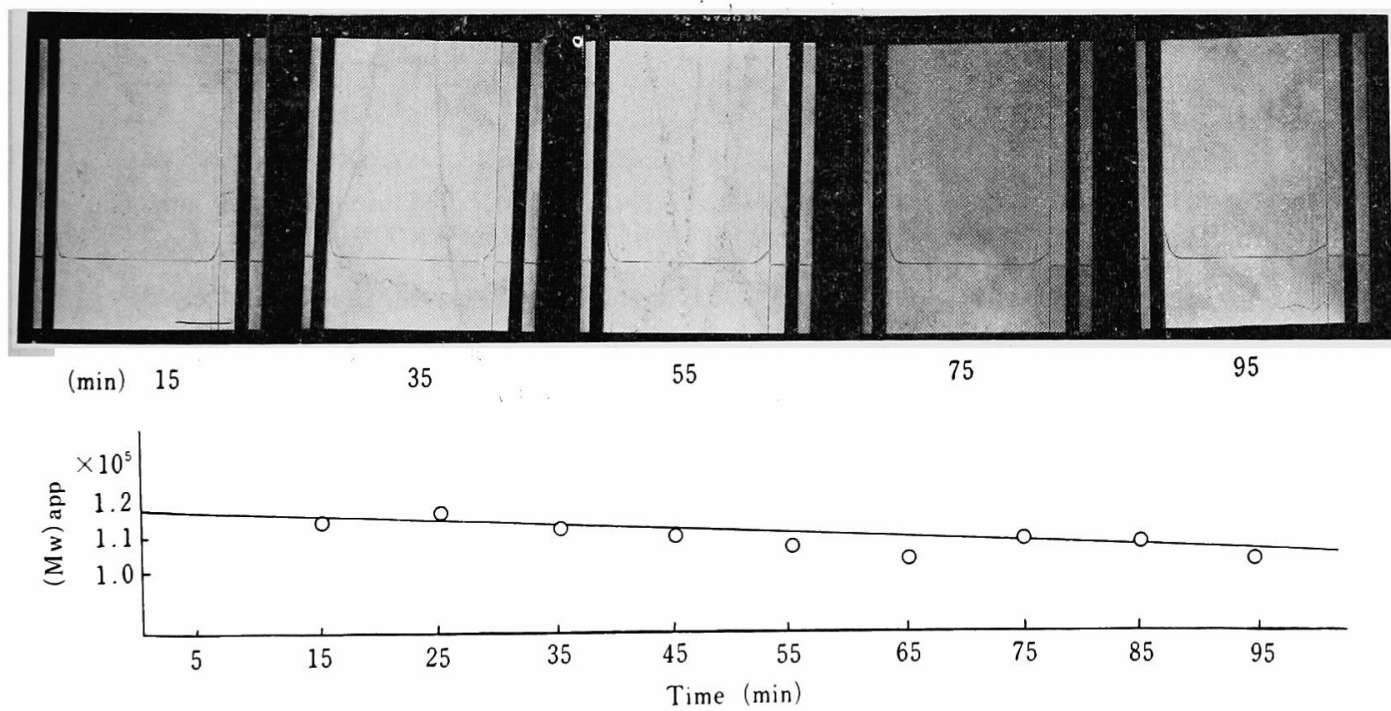

FIG. 2. Archibald Run of $0.96 \%$ Urate Oxidase in $0.033 \mathrm{M} \mathrm{Na}_{2} \mathrm{HPO}_{4}, 11,000 \mathrm{rpm}, 26^{\circ} \mathrm{C}$. 


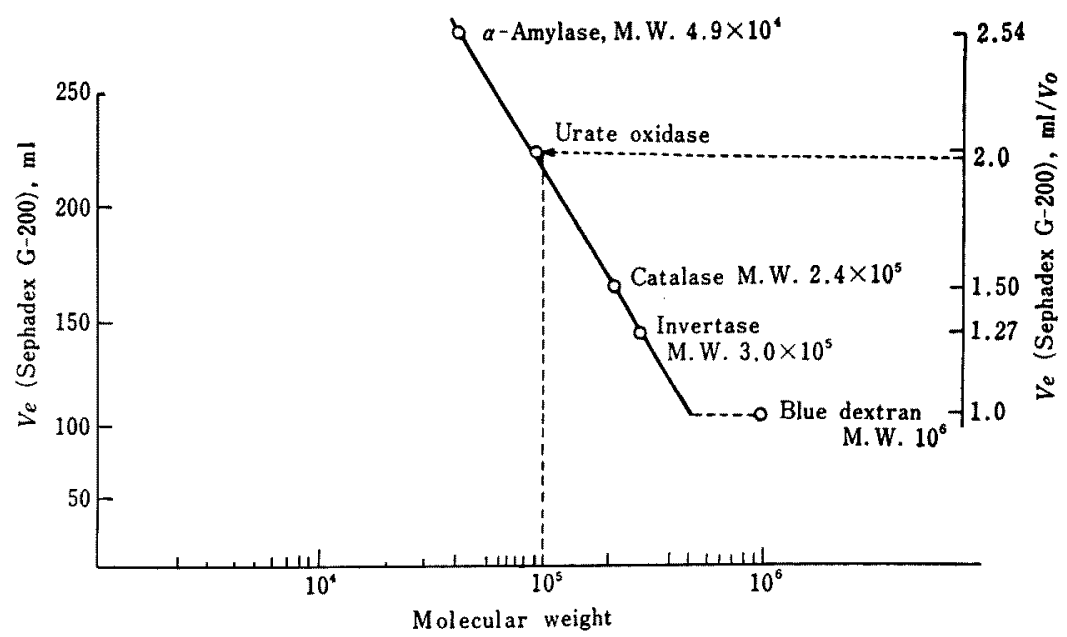

Plots of Elution Volumes, $V e$, versus $\log$ of Molecular Weights of

Proteins on Sephadex G-200 Column.

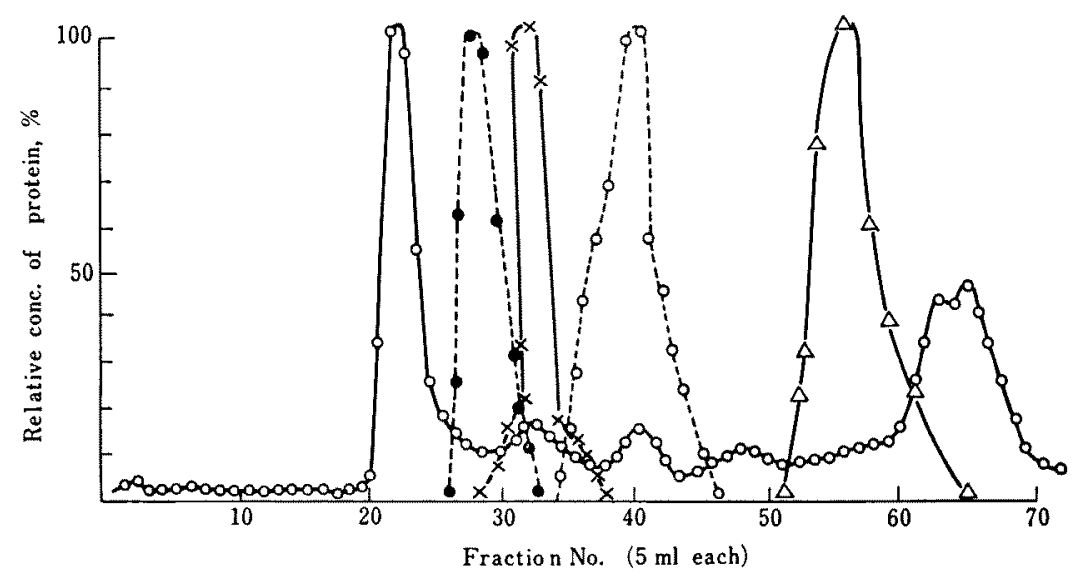

FIG. 3. Gel Filtration of Several Enzyme Proteins.

(Column; $1.9 \times 18.5 \mathrm{~cm}$ ).

$\bigcirc-O, E^{280} ;--\odot$, invertase (yeast invertase); $\times-\times$, catalase; $\triangle-\triangle, B a c$. subtilis amylase; $\mathrm{O}---\mathrm{O}$, yeast urate oxidase.

\section{Isoelectric point of the enzyme}

Isoelectric point of the enzyme was determined by the density electrofocusing method in which Ampholine (KLB 8131) was used as the $\mathrm{pH}$ gradient from 3 to 10 and sucrose, as the density gradient, respectively. In Fig 4 is illustrated the result showing that the iso- electric point of the enzyme is 5.4 .

\section{Absorption spectra of the purified enzyme}

The ultraviolet absorption pattern of the purified enzyme has been reported previously. However, the enzyme solution was found to show a slight absorption at $410 \mathrm{~m} \mu$, as presented 




FIG. 4. Isoelectrofocusing Density Column Chromatography of the Yeast Urate Oxidase. $\left(600 \mathrm{~V}, 7^{\circ} \mathrm{C}, 40 \mathrm{hr}\right)$.



FIG. 5. Absorbancy of the Yeast Urate Oxidase.

-, 13.0 mg enzyme per $\mathrm{ml}$ of $1 / 500 \mathrm{M} \mathrm{Na}_{2} \mathrm{HPO}_{4}$;

$\cdots, 13.0 \mathrm{mg}$ enzyme $+1 / 100 \mathrm{M} \mathrm{Na}_{2} \mathrm{~S}_{2} \mathrm{O}_{4}$. in Fig. 5. Absorbancy at this wavelength of the enzyme was about $3 \%$ of that at $280 \mathrm{~m} \mu$.

\section{Metal analyses of the enzyme preparation}

In this experiment, the enzyme preparations at various steps of purification procedure (See Diagram 1) were analysed in regard to iron and copper. After dialysis against a solution of $10^{-3} \mathrm{M}$ borate buffer containing $10^{-3} \mathrm{M}$ EDTA, $\mathrm{pH} 8.6$, overnight in the cold, the enzyme samples were cinerated in a porcelain crucible with a small quantity of $0.1 \mathrm{~N}$ nitric acid. The ash obtained here was dissolved in $0.1 \mathrm{~N}$ sulfuric acid and hydroxylamine was added to it in order to reduce iron to ferrous ion. Then, an aliquot of the solution was mixed with the saturated solution of o-nitrosoresorsinol monomethyl ether, and the color remaining in the aqueous phase was measured at $700 \mathrm{~m} \mu$ after extraction with carbon tetrachloride. Iron quantity was calculated from this color value comparing with the standard curves prepared using solutions containing known amounts of ferrous ion.

Another aliquot of the solution dissolving the ash of the enzyme was analysed for copper by atomic absorption spectrophotometory. The results in Table $I$ indicate that the purified enzyme preparation contains iron in amounts from 0.7 to nearly one atom per mole of the

Table I. Analytical Data of Copper and Iron of the Yeast Urate Oxidase

\begin{tabular}{|c|c|c|c|c|c|c|c|c|c|}
\hline \multirow[b]{2}{*}{$\begin{array}{l}\text { Purification } \\
\text { step* }\end{array}$} & \multirow[b]{2}{*}{ Enzyme sample } & \multirow[b]{2}{*}{$\begin{array}{c}\text { Activity } \\
\text { per } \\
\text { ml }\end{array}$} & \multirow[b]{2}{*}{$\begin{array}{l}\text { Specific } \\
\text { activity }\end{array}$} & \multicolumn{3}{|c|}{$\mathrm{Cu}$} & \multicolumn{3}{|c|}{$\mathrm{Fe}$} \\
\hline & & & & $\begin{array}{l}r \\
\text { per } \\
\mathrm{ml}\end{array}$ & $\begin{array}{l}\text { Activity } \\
\text { per } \\
\mu \text { atom }\end{array}$ & $\begin{array}{c}\mu \text { atom } \\
\text { per } 120 \mathrm{mg} \\
\text { protein }\end{array}$ & $\begin{array}{c}\gamma \\
\text { per } \\
\mathrm{ml}\end{array}$ & $\begin{array}{l}\text { Activity } \\
\text { per } \\
\mu \text { atom }\end{array}$ & $\begin{array}{c}\mu \text { atoms } \\
\text { per } 120 \mathrm{mg} \\
\text { protein }\end{array}$ \\
\hline 4 & $\begin{array}{l}\text { Yeast extracts, salted out } \\
\text { and dialysed }\end{array}$ & 18.89 & 0.31 & 0.43 & & & 2.85 & & \\
\hline 5 & $\begin{array}{l}\text { After first chromotography } \\
\text { by DEAE-cellulose }\end{array}$ & 55.84 & 3.87 & 0.14 & 25382 & 0.21 & 2.09 & 1509 & 0.36 \\
\hline 6 & After rechromatography & 81.76 & 8.21 & 0.11 & 48094 & 0.12 & 2.24 & 2042 & 0.52 \\
\hline 8 & $\begin{array}{l}\text { After gel filtration } \\
\text { and desalting }\end{array}$ & & & & & & & & \\
\hline & Experiment 1 & 125.65 & 10.38 & 0.40 & 19944 & 0.06 & 3.17 & 2204 & 0.67 \\
\hline & Experiment 2 & 90.53 & 10.64 & 0.31 & 18475 & 0.07 & 3.58 & 1414 & 0.96 \\
\hline & Experiment 3 & 105.32 & 11.01 & 0.30 & 22407 & 0.06 & 3.00 & 1965 & 0.79 \\
\hline
\end{tabular}

\footnotetext{
* See Diagram 1.
} 
enzyme protein. On the other hand, the content of copper was much less as compared with iron and, if calculated on the assumption that one atom of copper contains per mole of the enzyme protein, the molecular weight of the enzyme would be more than $1.0 \times 10^{6}$.

The presence of iron in the enzyme preparation was also clearly observed in the test of electron spin resonance (Fig. 6). Also, this finding indicates that the metal exists as ferric ion in the enzyme preparation. On the other hand, the radioactivation analysis (Fig. 7)

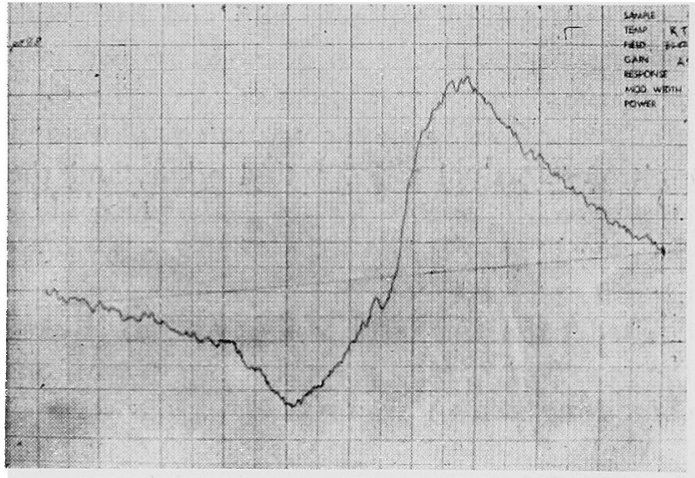

FIG. 6. ESR Spectra of the Yeast Urate Oxidase.

$\left(9.24 \mathrm{mg}\right.$ enzyme per $\mathrm{ml}$ of $0.002 \mathrm{M} \mathrm{Na}_{2} \mathrm{HPO}_{4}$, $\mathrm{pH}$ 7.8; modulation amplitude, 20 gauss; $25^{\circ} \mathrm{C}$ ). revealed that the enzyme contains only a trace amount of copper and the molecular weight of the enzyme calculated on the above assumption would be again more than $10^{6}$, as was obtained in the test of Table I.

\section{Inhibitors of the enzyme}

Effects of several inhibitors on the purified enzyme were investigated. As shown in Fig. 8 , the enzyme activity was reduced to a half by the addition of $3.2 \times 10^{-7} \mathrm{M}$ of $\mathrm{Hg}^{2+}, 2.5 \times$ $10^{-6} \mathrm{M}$ of PCMB, $1.3 \times 10^{-6} \mathrm{M}$ of $\mathrm{CN}^{-}$and $5.0 \times$ $10^{-5} \mathrm{M}$ of $\mathrm{Cu}^{2+}$ to the enzyme reaction mixture containing $0.02 \mathrm{unit} / \mathrm{ml}$ of the enzyme activity in $0.067 \mathrm{M}$ borate buffer, $\mathrm{pH} 8.4 \sim 8.5$.

In Fig. 9 are shown the effects of the inhibitors on the enzyme on incubation without the substrate. The inactivation occurred almost instantaneously by the addition of those inhibitors and the degree of inactivation was quite a function of concentration of the inhibitors. Inactivation of the enzyme caused by $\mathrm{Hg}^{2+}$ and PGMB, however, was reversed almost completely by the addition of certain reducing agents, as given in Table II.

On the other hand, the purified enzyme was not affected by the addition of reducing agents. Also, the enzyme was only slightly

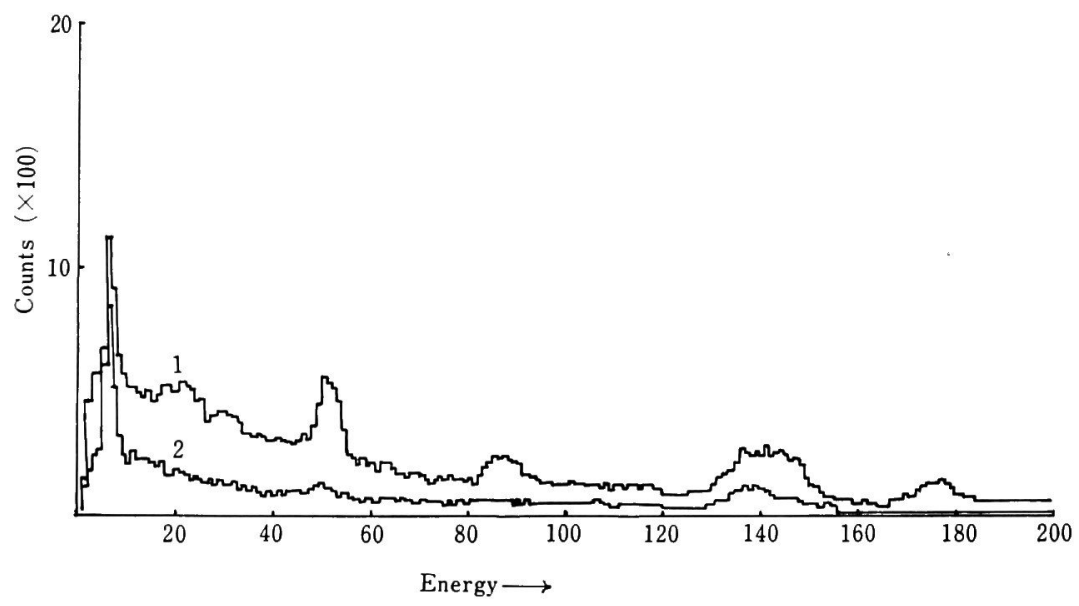

FIG. 7. Radioactivation Analysis of Copper of the Yeast Urate Oxidase. $1,2.65 \times 10^{-3} \mathrm{mg}$ of $\mathrm{Cu}^{2+} ; 2,5.1 \mathrm{mg}$ of Urate Oxidase. 
TABLE II. Reactivation OF Yeast URATE Oxidase

(Added $2.5 \times 10^{-4} \mathrm{M}$ reducing agents to the enzyme inactivated with $10^{-4} \mathrm{M} \mathrm{HgCl}_{2}$ or $\mathrm{PCMB}$ and incubated at $25^{\circ} \mathrm{C}$ for $60 \mathrm{~min}$.)

\begin{tabular}{ccccccc}
\hline Inactivator & Cysteine & $\mathrm{BAL}$ & $\mathrm{Na}_{2} \mathrm{~S}_{2} \mathrm{O}_{4}$ & Glutathione & $\mathrm{NaBH}_{4}$ & $\mathrm{Na}_{2} \mathrm{~S}$ \\
\hline $\mathrm{PCMB}$ & $87 \%$ & $88 \%$ & $6 \%$ & $91 \%$ & $73 \%$ & $88 \%$ \\
$\mathrm{HgCl}_{2}$ & 90 & 111 & 6 & 87 & 58 & 112 \\
\hline
\end{tabular}

Table III. Effects of Several Reagents on URAte Oxidase

(1/20 M borate buffer, $\mathrm{pH} 8.5,25^{\circ} \mathrm{C}, 60 \mathrm{~min}$.)

\begin{tabular}{lcccccccc} 
Reagent & None & EDTA & $\mathrm{H}_{2} \mathrm{O}_{2}$ & $\begin{array}{c}\mathrm{H}_{2} \mathrm{O}_{2} \\
+\mathrm{Fe}_{2}\left(\mathrm{SO}_{4}\right)_{3}\end{array}$ & $\mathrm{~K}_{4} \mathrm{Fe}(\mathrm{CN})_{6} \begin{array}{c}\text { o-Phenan- } \\
\text { throline }\end{array}$ & $\begin{array}{c}\alpha \cdot \alpha^{\prime}- \\
\text { Dipyridyl }\end{array}$ & $\mathrm{BAL}$ \\
\hline $\begin{array}{l}\text { Conc., M } \\
\begin{array}{c}\text { Remaining } \\
\text { activity, } 8\end{array}\end{array}$ & - & $2.5 \times 10^{-4}$ & $2.0 \times 10^{-4}$ & $\begin{array}{l}1.0 \times 10^{-5} \\
+2.5 \times 10^{-4}\end{array}$ & $2.5 \times 10^{-4}$ & $2.5 \times 10^{-4}$ & $2.5 \times 10^{-4}$ & $1.0 \times 10^{-4}$ \\
\hline
\end{tabular}

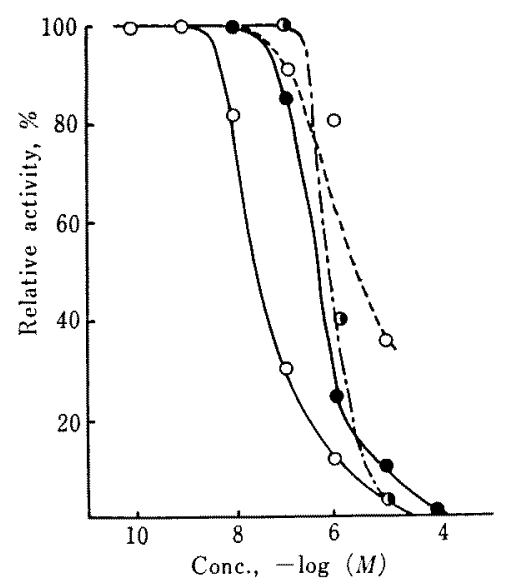

FIG. 8. Effects of Several Inhibitors on the Activity.

(The enzyme reaction was carried out under the same condition as the standard activity assay.)

$\mathrm{O}-\mathrm{O}, \mathrm{Hg}^{2+} ; 0-\bullet, \mathrm{PCMB} ;-\mathrm{CN}, \mathrm{CN}^{-}$; $\mathrm{O}-\cdots, \mathrm{Cu}^{2+}$.

affected by several oxidizing agents, even in the presence of ferric ion. The enzyme also was not inactivated by such chelating agents as EDTA and o-phenanthroline (Table III).

\section{Effects of urea}

Time courses of the inactivation of the enzyme with various concentrations of urea

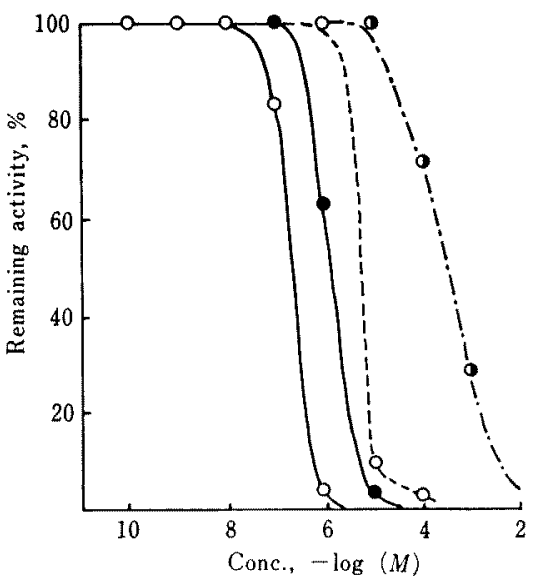

FIG. 9. Effects of Various Ions on Stability of the Enzyme.

(The enzyme (1/15 $\mathrm{M}$ borate buffer, $\mathrm{pH} 8.4$ ) was incubated with the inhibitor indicated at $25^{\circ} \mathrm{C}$ for $2 \mathrm{hr}, \mathrm{pH} 8.4$, and after addition of EDTA and dilution of the mixture upto fifty-fold volumes with $1 / 50 \mathrm{M}$ borate buffer, $\mathrm{pH} 8.4$, the remaining activity was determined.)

$\mathrm{O}-\mathrm{O}, \mathrm{Hg}^{2+}$;

$\mathrm{O}-\mathrm{O}, \mathrm{Cu}^{2+}$.

are illustrated in Fig. 10. Of particular interest was that the inactivation rate by urea was greatly increased by the addition of reducing agents such as BAL (Fig. 11). The presence 
of EDTA in this case appeared to somewhat protect the enzyme from the inactivation with urea.

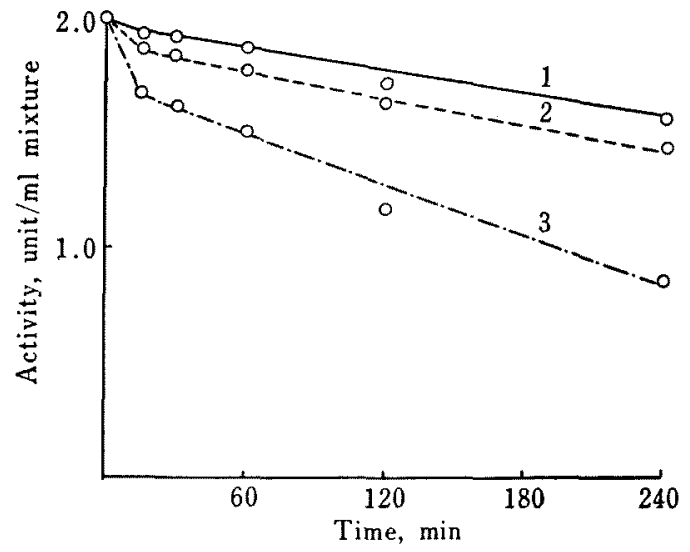

FIG. 10. Inactivation of Yeast Urate Oxidase with Urea.

$\left(25^{\circ} \mathrm{C}, 1 / 50 \mathrm{M}\right.$ borate buffer, $\left.\mathrm{pH} 8.4\right)$.

Curve $1,3.0 \mathrm{M} ; 2,5.0 \mathrm{M} ; 3,7.0 \mathrm{M}$ of Urea.

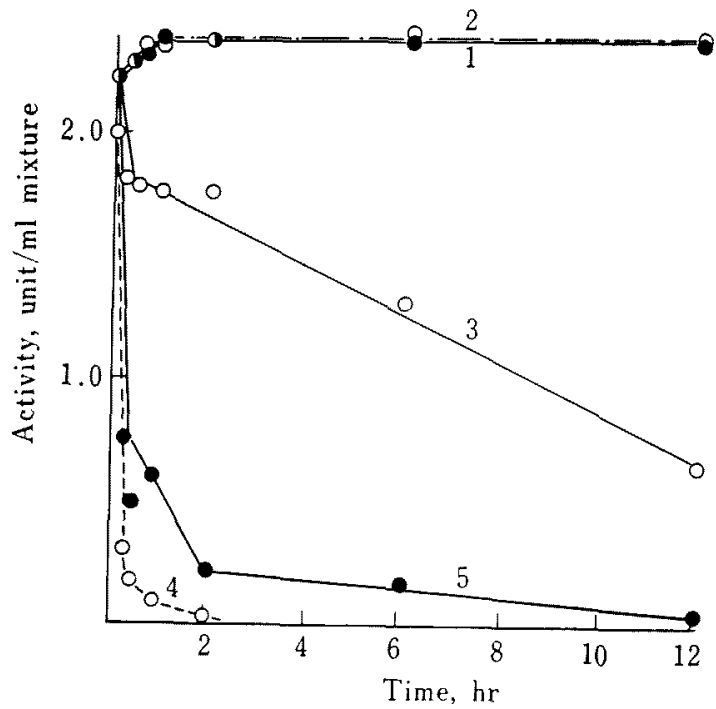

FIG. 11. Effects of Additions on the Inactivation of Yeast Urate Oxidase with Urea.

$\left(1 / 50 \mathrm{M}\right.$ borate buffer, $\mathrm{pH} 8.4 \sim 8.5,25^{\circ} \mathrm{C}$ )

Curve 1, 0.3 M BAL; 2, $0.3 \mathrm{M} \mathrm{BAL}+0.01 \mathrm{M}$ EDTA; 3, 6.0 M Urea; 4, 6.0 M Urea +0.3 M BAL; $5,6.0 \mathrm{M}$ Urea $+0.3 \mathrm{M} \mathrm{BAL}+0.01 \mathrm{M}$ EDTA.

\section{DISCUSSION}

Mahler et $a .^{2,3)}$ have reported that urate oxidase isolated from swine liver is a copper enzyme. The present study, however, led us to the conclusion that urate oxidase of Candida utilis was not a copper enzyme because of its extremely low content of the metal. Contrarily, the purified enzyme preparation contained iron of nearly one atom per mole of enzyme protein, although no enzymic role of the metal was studied in the present work.

Truscoe et al..$^{(-6)}$ have published several papers on the effects of various thiols on urate oxidase. They found that the enzyme extracted from ox-kidney greatly increased its activity upon the addition of thiols such as thioglycollate, glutathione, etc., although the enzyme was rather inactivated by cystein of more than a certain concentration. Our purified enzyme preparation isolated from Candida utilis was extremely sensitive to some heavy metallic ions, but the enzyme inactivated with $\mathrm{Hg}^{2+}$ and $\mathrm{PCMB}$ recovered its activity by the addition of thiols. This finding clearly indicates that the enzyme possesses chemically reactive $\mathrm{SH}$ group(s) which closely relates to the activity or to the active structure of the enzyme. During purification of urate oxidase from the yeast extracts obtained by the method of salt shock followed by dialysis against a slightly alkaline solution of low ionic strengths, the addition of reducing agents such as sodium hydrosulfite was found to effect stabilizing the enzyme and sometimes increasing the enzyme activity. However, the purified enzyme of which specific activity was raised to $10.5 \sim 11$ was not affected with any reducing agent. The addition of reducing agents rather resulted in a decrease of specific activity of the enzyme. A long storage of the enzyme solution also caused a decrease in the specific activity even in a sealed tube and in the cold, and this aged enzyme was shown to be separated into two fractions on gel filtration by a column of Sephadex G-200 as presented in 


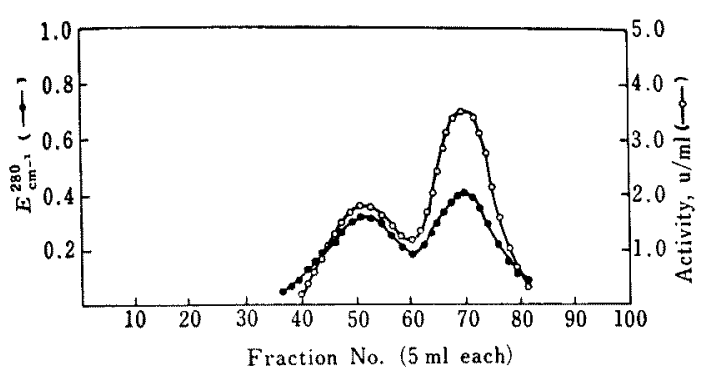

FIG. 12. Gel Filtration by Sephadex G-200 of an Aged Sample of Yeast Urate Oxidase.

$\left(0.02 \mathrm{M}\right.$ borate buffer, $\left.\mathrm{pH} 8.5,4^{\circ} \mathrm{C}\right)$.

Fig. 12, the specific activity of the second fraction being the same as the one before storage while that of the first fraction, only about a half of the original. Such phenomena of decrease in specific activity during storage of the enzyme were found to be apt to occur in the presence of reducing agents. For prevention of decrease of specific activity of the purified enzyme, EDTA was most effective among the chemicals so far tested.

In the present paper were found certain thiols to greatly stimulate the inactivation of yeast urate oxidase with urea. However, in this case, EDTA appeared to somewhat protect the enzyme from the inactivation. These facts seem to be related with the finding by Truscoe et al..$^{4-6)}$ that cysteine of more than a certain concentration rather inactivates the urate oxidase of ox-kidney. They suggested that cysteine might act to break the intramolecular disulfide bonds of the enzyme, with consequent disruption of the active center.

The yeast urate oxidase showed a small shoulder at $410 \mathrm{~m} \mu$ in the absorption spectrum. Mahler et al. ${ }^{2,31}$ have also observed a shoulder in the spectrum of the enzyme of swine liver. This shoulder of our enzyme preparation was significantly decreased by the addition of hydrosulfite and thus this absorption did not seem to be due to FAD. Studies for clarifying the reason why the purified enzyme is not stabilized by certain thiols, despite the enzyme is considered as a SH-enzyme, will be left in future, together with the study of the active structure or active center of the enzyme.

The authors express their sincere thanks to Dr. M. Kinoshita of Faculty of Engineering, Dr. M. Tsurumaki of Faculty of Science of Osaka City University, Drs. Y. Kiso and M. Kobayashi of the Research Reactor Institute of Kyoto University, and Dr. K. Tomoda of Microbiological Research Laboratory of Takeda Chemical Industries, for their kind help in analyses of metals of the enzyme preparation. 